\title{
Raman, crystallographic and chemical characterization of roméite-group minerals
}

\author{
G. A. de C. Lopes ${ }^{1}$, D. Atencio ${ }^{2}$, M. B. de Andrade ${ }^{1}$ \\ ${ }^{1}$ São Carlos Institute of Physics, Av. Trabalhador São-carlense, 400, Pq. Arnold Schimidt-CEP 13566-590, São Carlos-SP - Brazil, \\ ${ }_{2}^{2}$ Institute of Geosciensces, Rua do Lago, 562, Butantã - CEP 05508-080, São Paulo-SP - Brazil \\ g.anderson@ifsc.usp.br
}

The roméite-group $[1,2]$ is part of the pyrochlore supergroup and comprises some cubic oxides of $\mathrm{A}_{2-\mathrm{m}} \mathrm{B}_{2} \mathrm{X}_{6-\mathrm{w}} \mathrm{Y}_{1-\mathrm{n}}$ formula in which $\mathrm{Sb}^{5+}$ predominates in the $\mathrm{B}$-site. Indices $\mathrm{m}, \mathrm{w}$ and $\mathrm{n}$ indicate vacancies in $\mathrm{A}, \mathrm{X}$ and $\mathrm{Y}$ crystallographic sites, respectively. A-site is typically occupied by cations with ionic radii greater than $1.0 \AA$ or $\mathrm{H}_{2} \mathrm{O}$, whereas $\mathrm{X}$-site is usually occupied by $\mathrm{O}^{2-}$, but smaller amounts of $\mathrm{OH}^{-}$or $\mathrm{F}^{-}$are also commonly found. Finally, $\mathrm{Y}$-site is typically occupied by anions $\mathrm{O}^{2-}, \mathrm{OH}^{-}$or $\mathrm{F}^{-}$; however, large ionic radii monovalent cations

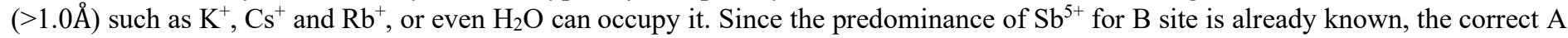
and $\mathrm{Y}$ main occupants determine different minerals in the group and are important for the discovery of new mineral species [3]. As a source of $\mathrm{Sb}$, the roméite-group minerals are economically relevant, since $\mathrm{Sb}$ is present in different applications, from cosmetic industry to the metal alloy production. However, only five roméite-group mineral species, namely fluorcalcioroméite, hydroxycalcioroméite, hydroxyferroroméite, oxycalcioroméite, and oxyplumboroméite have been approved by IMA. Many others can probably be discovered from possible chemical substitutions at crystallographic sites. This study analysed three different samples and determined their chemical composition by electron microprobe analysis and Raman spectra and crystal structure obtained from single-crystal X-ray diffraction. The first sample occurs in Kalugeri Hill, Babuna Valley, Jakupica Mountains, Nezilovo,Veles, Macedonia, whereas the other two occur in Prabornaz Mine, Saint Marcel, Valle d'Aosta, Italy. Sample 1 was identified as fluorcalcioroméite, and samples 2 and 3 as hydroxycalcioroméite. These are the first descriptions of these mineral species at the mentioned occurrences.

All samples belong to the cubic crystal system, space group $F d \overline{3 m}, \mathrm{Z}=8$, where $a=10.2881(13) \AA, \mathrm{V}=1088.9(4) \AA^{3}$ for sample $1, a$ $=10.2970(13) \AA, \mathrm{V}=1091.8(4) \AA^{3}$ for sample 2 , and $a=10.289(6) \AA, \mathrm{V}=1089.3(19) \AA^{3}$ for sample 3 . The crystal structure refinements led to the convergence of $\mathrm{R}$-factors of the three samples: 1) $\mathrm{R}_{1}=0.016 . w \mathrm{R}_{2}=0.042$ and Goodness-of-fit $\left.=1.176 ; 2\right) \mathrm{R}_{1}=0.230$. $w \mathrm{R}_{2}$ $=0.049$ and Goodness-of-fit $=1.095 ; 3) \mathrm{R}_{1}=0.029 . \mathrm{wR}_{2}=0.090$ and Goodness-of-fit $=1.338$. Bond-valence calculations validated the crystal structure refinements determining the correct valences at each crystallographic site. Discrepancies observed in the $\mathrm{Sb}^{5+}$ bondvalence calculations were solved with the use of the proper bond valence parameters revised by Mills et al. (2009) [4]. The resulting structural formulas were $\left(\mathrm{Ca}_{1.29} \mathrm{Na}_{0.55} \square_{0.11} \mathrm{~Pb}_{0.05}\right)_{\Sigma=2.00}\left(\mathrm{Sb}_{1.71} \mathrm{Ti}_{0.29}\right)_{\Sigma=2.00}\left(\mathrm{O}_{5.73} \mathrm{OH}_{0.27}\right)_{\Sigma=6.00}\left(\mathrm{~F}_{0.77} \mathrm{O}_{0.21} \mathrm{OH}_{0.02}\right)_{\Sigma=1.00}$ for sample 1, $\left(\mathrm{Ca}_{1.30} \mathrm{Ce}_{0.51} \square_{0.19}\right)_{\Sigma=2.00}\left(\mathrm{Sb}_{1.08} \mathrm{Ti}_{0.92}\right)_{\Sigma=2.00} \mathrm{O}_{6.00}\left(\mathrm{OH}_{0.61} \mathrm{O}_{0.21} \mathrm{~F}_{0.18}\right)_{\Sigma=1.00}$ for sample 2, and $\left(\mathrm{Ca}_{1.61} \square 0.24 \mathrm{Na}_{0.15}\right)_{\Sigma=2.00}\left(\mathrm{Sb}_{1.80} \mathrm{Ti}_{0.20}\right)_{\Sigma=2.00} \mathrm{O}_{6.00}$ $\left(\mathrm{OH}_{0.48} \mathrm{~F}_{0.35} \mathrm{O}_{0.17}\right)_{\Sigma=1.00}$ for sample 3. The Raman spectra of all samples exhibited the characteristic bands of chemical bonds present in roméite-group minerals - the most evident one corresponded to the stretching of $\mathrm{Sb}-\mathrm{O}$ bond around $510 \mathrm{~cm}^{-1}$. Peaks around 1600 and $3600 \mathrm{~cm}^{-1}$ were observed, confirming the presence of water in the structure.

[1] Atencio, D., Ciriotti, M., Andrade, M. (2013). Mineralogical Magazine. 77, pp. 467-473.

[2] Mills, S. J. (2017). European Journal of Mineralogy. 29, pp. 307-314.

[3] Atencio, D., et al. (2010). Canadian Mineralogist. 48, pp. 673-698.

[4] Mills, S. J., et al. (2009). Zeitschrift für Kristallographie. 229, pp. 423-431.

Keywords: Raman spectra; crystal structure; single-crystal XRD; roméite-group; bond-valence

The authors wish to thank the São Paulo Research Support Foundation (FAPESP) for the support by process number 2013/03487-8. 